\title{
COMPARATIVE DYNAMIC ANALYSIS OF VALUE ADDED CREATED BY INDUSTRY “FORESTRY AND LOGGING" IN THE BALTIC STATES AND FINLAND
}

\author{
Andrejs Jaunzems \\ Ventspils University of Applied Sciences, Latvia \\ jaunzems@venta.lv
}

\begin{abstract}
The goal of this paper is to carry out the comparative dynamic analysis of value added as part of total output created by the industry A02 (Forestry and logging) in the Baltic States (LTA, LTU, EST) and Finland $(F I N)$ for the period of 2000-2014. The empirical material of the research is the "National Input-Output tables for the period 2000-2014" available on the World Input-Output Database (WIOD) with its unified structured statistical information in monetary terms. The discussion part of the paper is devoted to identification of the most important reasons, which cause significant differences in the economic efficiency of industry A02 in LTA, LTU, $E S T, F I N$. The time series of value added as part of total output in the industry $A 02$ are investigated. The comparative approach allows us to recognize sufficient differences in the shape of value added trends in the industry A02 in different countries. Coefficient of variation for value added calculated using trend corrected data is offered as original industry dynamics attribute. The version of input-output model is the theoretical tool to establish the most important reasons, which cause significant differences in the productivity of the industry A02 in LTA, LTU, EST, FIN (in the sense of value added creation).
\end{abstract}

Keywords: industries $A 02, C 16, C 31 \_C 32, F$, input-output model, value added time series, interindustry coefficients, Leontief inverse, allocation coefficients, Ghosh inverse.

\section{Introduction}

The aim of the study is to carry out the comparative dynamic analysis of value added created by the industry $A 02$ (Forestry and logging) in the Baltic States - Latvia (LTA), Lithuania (LTU), Estonia $(E S T)$ and Finland $(F I N)$ for the period of 2000-2014 in order to identify the most important reasons, which cause significant differences in the economic efficiency of the industry A02 in LTA, LTU, EST, FIN. Industry A02 is considered in interconnection with the industries C16 (Manufacture of wood and of products of wood and cork, except furniture; manufacture of articles of straw and plaiting materials), C31_C32 (Manufacture of furniture; other manufacturing), $F$ (Construction). The theoretical background of the current research is the Input-Output analysis, the present content of which is explored, for example, in the relevant book Input-Output analysis. Foundations and extensions by Ronald E. Miller, Peter D. Blair, and other academic publications. The empirical material of the study is the "National Input-Output tables for the period 2000-2014" available on the World Input-Output Database (WIOD).

In the paper the time series of value added per unit of total output in LTA, LTU, EST, FIN are investigated. The trend in functional form $v=a \cdot \tau^{b}+c$ for each of time series is calculated. With help of the trend we classify the shape of dynamics of value added of four types: increasing convex, increasing concave, decreasing convex, decreasing concave. The comparative approach allows us to recognize sufficient differences in the shape of value added trends in the industry $A 02$ in different countries. Coefficient of variation for value added during the period of 2000-2014 calculated using trend corrected data is offered as original industry dynamics attribute what is, in quantitative terms, a measure of the level of dynamic's regularity.

The main tool applied to establish the most important reasons, which cause significant differences in the productivity of the industry A02 in LTA, LTU, EST, FIN (in the sense of value added creation), is the version of the input-output model. The sufficient differences between the relevant interindustry coefficients and allocation coefficients, and the relevant elements of the Leontief inverse and Ghosh inverse as well in corresponding industries of LTA, LTU, EST, FIN are useful in explaining the distinctions of value added creation power. The further investigations provided together with industry A02 experts have to be oriented towards explaining the most essential differences between interindustry coefficients, allocation coefficients, elements of the Leontief inverse and Ghosh inverse in order to elaborate adequate management decisions.

Note: all tables and all figures in the current paper are created by the author using NIOT data, mathematical models and Microsoft Excel tools. 


\section{Materials and methods}

As mentioned in the introduction, the empirical material of the study is the "National InputOutput tables (NIOT) for the period of 2000-2014" available on the World Input-Output Database (WIOD) with its unified structured statistical information in monetary terms (www.wiod.org). The first version of the World Input-Output Database was constructed in the framework of the official WIOD Project, funded by the European Commission as part of the 7th Framework Programme. Data for 56 sectors are classified according to the International Standard Industrial Classification revision 4. The NIOT are compiled in current prices, expressed in millions of US dollars. Let us stress that the NIOT are assumed in the current research as indisputable. It is the reason to be in opinion that WIOD will be carried on for the further time period and in that way WIOD will grow as very fruitful empirical inventory for scientific and management needs.

The first step in our study is the investigation of the following time series of value added as part of total output:

$$
\{v(L T A ; A 02 ; t), v(L T U ; A 02 ; t), v(E S T ; A 02 ; t), v(F I N ; A 02 ; t) \mid t=2000,2001, \ldots, 2014\} .
$$

Let us explain these notations with help of an example. The equality $v(L T A ; A 02 ; 2014)=0.34$ means: the value added with respect to unit of total output (on monetary terms in current prices) in the country LTA (Latvia), in the industry A02 (Forestry and logging), in the year 2014 is 0.34 . Therefore, in Latvia in 2014 each euro of total output in the industry $A 02$ creates 0.34 euros value added. But, for example, $v(F I N ; A 02 ; 2014)=0.71 ; v(E S T ; A 02 ; 2014)=0.43$.

Apparently, the question arises: 0.34 in LTA versus 0.71 in FIN and 0.43 in EST; what is the reason?

The trend in functional form $v=a \cdot \tau^{b}+c$ for each of time series using the least square method is calculated. With help of such trend the shape of value added dynamics is classified in four types: increasing convex, increasing concave, decreasing convex, decreasing concave. The comparative approach allows us to recognize sufficient differences in the shape of value added trends in the industry A02 in different countries. Coefficient of variation for value added during the period of 20002014 calculated by using trend corrected data is offered as original industry dynamics attribute what in quantitative terms measures the level of industry dynamic's regularity.

The main tool applied to discover the most important reasons, which cause significant differences in the productivity of the industry A02 in LTA, LTU, EST, FIN (in the sense of value added creation power), is the original version of the input-output model. Let us shortly expound the theoretical inputoutput framework and the methods used.

The original version of the input-output model is specifically constructed by the author with regard to the given structured statistical information NIOT, what represents the direct and dual systems of accounting balancing equations in millions of dollars. In order to explore the structure of the constructed model the aggregated NIOT for LTA, 2014 is shown in Table 1.

Table 1

Latvia, 2014, aggregated NIOT compiled in current prices, expressed in millions of US dollars

\begin{tabular}{|c|c|c|c|c|c|c|c|c|c|c|c|c|c|}
\hline Code & Origin & A02 & C16 & C31_C32 & $\mathbf{F}$ & others & CONS_h & CONS_np & CONS_g & GFCF & INVEN & EXP & GO \\
\hline A02 & Domestic & 299 & 515 & 5 & 4 & 46 & 120 & 0 & 19 & 1 & -21 & 260 & 1,248 \\
\hline $\mathrm{C} 16$ & Domestic & 99 & 454 & 48 & 206 & 99 & 150 & 0 & 6 & 14 & 4 & 1,608 & 2,687 \\
\hline C31_C32 & Domestic & 1 & 2 & 1 & 3 & 22 & 64 & 0 & 1 & 69 & -76 & 347 & 434 \\
\hline $\mathrm{F}$ & Domestic & 2 & 4 & 1 & 2,306 & 1,061 & 194 & 0 & 5 & 3,573 & -7 & 217 & 7,357 \\
\hline others & Domestic & 239 & 603 & 104 & 1,643 & 18,955 & 11,665 & 361 & 5,211 & 1,803 & 128 & 12,287 & 53,000 \\
\hline A02 & Imports & 13 & 24 & 0 & 0 & 2 & 1 & 0 & 0 & 0 & 0 & 0 & 41 \\
\hline $\mathrm{C} 16$ & Imports & 18 & 101 & 12 & 51 & 20 & 8 & 0 & 0 & 3 & 0 & 0 & 214 \\
\hline C31_C32 & Imports & 1 & 4 & 3 & 12 & 59 & 170 & 0 & 2 & 180 & 2 & 0 & 433 \\
\hline $\mathrm{F}$ & Imports & 0 & 1 & 0 & 67 & 56 & 17 & 0 & 0 & 3 & 1 & 0 & 146 \\
\hline others & Imports & 128 & 240 & 90 & 1,008 & 7,206 & 4,448 & 1 & 198 & 1,280 & 137 & 0 & 14,738 \\
\hline II_fob & TOT & 801 & 1,947 & 265 & 5,301 & 27,526 & 16,837 & 363 & 5,443 & 6,928 & 168 & 0 & 65,579 \\
\hline TXSP & TOT & 17 & 19 & 3 & 106 & 609 & 1,397 & 11 & 63 & 155 & 4 & 0 & 2,385 \\
\hline others & TOT & 7 & 20 & 6 & 56 & 289 & 562 & 0 & 9 & 83 & 7 & 0 & 1,040 \\
\hline VA & TOT & 424 & 701 & 160 & 1,894 & 24,575 & 0 & 0 & 0 & 0 & 0 & 0 & 27,754 \\
\hline $\mathrm{GO}$ & TOT & 1,248 & 2,687 & 434 & 7,357 & 53,000 & 18,796 & 375 & 5,516 & 7,165 & 179 & 14,719 & 111,476 \\
\hline
\end{tabular}

There are standard notations used in NIOT. 
(A) Industries:

- $\mathrm{A} 02$ = Forestry and logging;

- $\mathrm{C} 16=$ Manufacture of wood and of products of wood and cork, except furniture; manufacture of articles of straw and plaiting materials;

- C31_C32 = Manufacture of furniture, other manufacturing;

- $\mathrm{F}=$ Construction.

"Others" contains in aggregate form all others 52 sectors explored in the NIOT.

(B) The notations concerning components of final demand:

- CONS_h = Final consumption expenditure by households;

- CONS_np = Final consumption expenditure by non-profit organisations serving households (NPISH);

- CONS_g = Final consumption expenditure by government;

- $\mathrm{GFCF}=$ Gross fixed capital formation;

- $\quad$ INVEN $=$ Changes in inventories and valuables;

- $\mathrm{EXP}=$ Exports;

- $\mathrm{GO}=$ Total (gross) output at basic prices.

(C) The notations of the table lower part rows:

- II_fob = Total intermediate consumption;

- $\quad$ TXSP = Taxes less subsidies on products;

- $\mathrm{VA}=$ Value added at basic prices.

- "Others" means the aggregated following indicators:

- EXP_adj = Cif/fob adjustments on exports;

- $\quad$ PURR = Direct purchases abroad by residents;

- PURNR = Purchases on the domestic territory by non-residents;

- IntTTM = International Transport Margins.

Let us introduce notations used in our study. The balance of the first five rows

$$
(299+515+5+4+46)+(120+0+19+1-21+260)=1,248
$$$$
(99+454+48+206+99)+(150+0+6+14+4+1,608)=2,687
$$$$
(1+2+1+3+22)+(64+0+1+69-76+347)=434
$$$$
(2+4+1+2,306+1,061)+(194+0+5+3,573-7+217)=7,357
$$

$$
(239+603+104+1,643+18,955)+(11,665+361+5,211+1,803+128+12,287)=53,000 .
$$

we will record in form $r \operatorname{sum}(\boldsymbol{A})+\operatorname{rsum}(\boldsymbol{B})=\boldsymbol{X}$.

The balance of the rows 6-10 we will record as $\operatorname{rsum}(\boldsymbol{C})+\operatorname{rsum}(\boldsymbol{D})=\boldsymbol{M}$.

The balance of the rows 12-13 we will record as $\operatorname{rsum}(\boldsymbol{E})+\operatorname{rsum}(\boldsymbol{F})=\boldsymbol{N}$.

The balance of the row 14 we will record as $\operatorname{rsum}(\boldsymbol{V})=\boldsymbol{v}$.

The balance of the first 5 columns we will record as $\operatorname{csum}(\boldsymbol{A})+\operatorname{csum}(\boldsymbol{C})+\operatorname{csum}(\boldsymbol{E})+\boldsymbol{V}=\boldsymbol{X}^{\boldsymbol{T}}$.

The balance of the columns 6-11 we will record as $\operatorname{csum}(\boldsymbol{B})+\operatorname{csum}(\boldsymbol{D})+\operatorname{csum}(\boldsymbol{F})=\boldsymbol{Y}^{\boldsymbol{T}}$.

The vectors $\boldsymbol{X}, \boldsymbol{Y}, \boldsymbol{M}, \boldsymbol{N}$ are vector-columns. The vector $\boldsymbol{V}$ is vector-row.

As a result of dividing each column in the table by the corresponding total output or corresponding total final demand we get the proper matrices of coefficients $A, B, C, D, E, F, V$.

Let us stress that massive denoted by bold symbol contains absolute values of indicators, but massive denoted by corresponding normal symbols contains relative values - ratios. For example, the components of matrix A are interpreted as interindustry coefficients.

Now we can write down the direct and dual I-O models.

Direct I-O model:

$$
A X+B Y=X, C X+D Y=M, E X+F Y=N, V X=v .
$$


By definite conditions what in the real economy holds the direct I-O model can be rewritten in form:

$$
\boldsymbol{X}=S B \boldsymbol{Y},(C S B+D) \boldsymbol{Y}=\boldsymbol{M},(E S B+F) \boldsymbol{Y}=\boldsymbol{N}, V S B \boldsymbol{Y}=\boldsymbol{v},
$$

where matrix $S:=(I-A)^{-1}$ is so called Leontief inverse.

Dual I-O model:

$$
A^{T} \boldsymbol{P}+C^{T} \boldsymbol{P}^{1}+E^{T} \boldsymbol{P}^{2}+V^{T} \boldsymbol{v}=\boldsymbol{P}, B^{T} \boldsymbol{P}+D^{T} \boldsymbol{P}^{1}+F^{T} \boldsymbol{P}^{2}=1,
$$

where $\boldsymbol{P}, \boldsymbol{P}^{1}, \boldsymbol{P}^{2}$ are corresponding price indices vectors; $1=(1,1, \ldots, 1)^{T}$.

Using the Leontief inverse this system can be rewritten in form:

$$
\boldsymbol{P}=S^{T} C^{T} \boldsymbol{P}^{1}+S^{T} E^{T} \boldsymbol{P}^{2}+S^{T} V^{T} \boldsymbol{v},\left(B^{T} S^{T} C^{T}+D^{T}\right) \boldsymbol{P}^{1}+\left(B^{T} S^{T} C^{T}+F^{T}\right) \boldsymbol{P}^{2}+B^{T} S^{T} V^{T} \boldsymbol{v}=1 .
$$

As a result of dividing each row in the table by the corresponding number in the last column (total output, total import, total value added) we get the proper matrices of coefficients $A^{\prime}, B^{\prime}, C^{\prime}, D^{\prime}, E^{\prime}, F^{\prime}$, $V^{\prime}$.

As before, this massive contains relative values - ratios. For example, the components of the matrix $A^{\prime}$ are interpreted as allocation coefficients.

Now we can write the $\mathrm{I}-\mathrm{O}$ model in Ghosh form:

$$
\left(A^{\prime}\right)^{T} \boldsymbol{X}+\left(C^{\prime}\right)^{T} \boldsymbol{M}+\left(E^{\prime}\right)^{T} \boldsymbol{N}+\left(V^{\prime}\right)^{T} \boldsymbol{v}=\boldsymbol{X},\left(B^{\prime}\right)^{T} \boldsymbol{Y}+\left(D^{\prime}\right)^{T} \boldsymbol{M}+\left(F^{\prime}\right)^{T} \boldsymbol{N}=\boldsymbol{Y} .
$$

By definite conditions the first equation of model can be rewritten in form:

$$
\boldsymbol{X}=T^{T}\left(C^{\prime}\right)^{T} \boldsymbol{M}+T^{T}\left(E^{\prime}\right)^{T} \boldsymbol{N}+T^{T}\left(V^{\prime}\right)^{T} \boldsymbol{v},
$$

where matrix $T:=\left(I-A^{\prime}\right)^{-1}$ is so called Ghosh inverse.

The equalities of models are useful in interpreting the role of interindustry coefficients, allocation coefficients, and relevant for the industry $A 02$ elements of the Leontief inverse and Ghosh inverse as well, in the process of value added creation.

\section{Results and discussion}

Some notes about the concept of value added in microeconomics, macroeconomics and in the WIOD.

In microeconomics an acceptable definition of firm's created value added is given in the book [2] Economics by Äke Blomqvist, Paul Wonnacott, Ronald Wonnacott: "Value added. Value of the product sold less the cost of intermediate products bought from other firms".

The macroeconomic concept of value added created by an industry is explained in the European Central Bank Glossary: "value added (gross) is total output less the intermediate consumption". Eurostat definition: GDP = compensation of employees + gross operating surplus + net taxes on production and imports. The Input-Output model is necessary in order to understand logic of the definitions given by the ECB and Eurostat [4-6].

Let us critically remark that WIOD does not explore the structure of value added, and let us define this as a substantial deficiency, because it makes impossible to investigate the distribution of created wealth between different economic agents.

\section{Analysis of the industry $A 02$ value added time series (LTA, LTU, EST, FIN)}

Table 2 shows that the industry "Forestry and logging" (A02) plays an important role in the economies of LTA, EST, FIN. For example, in Latvia in 2014 the industry A02 created $1.5 \%$ of the total value added. Table 3 shows the industry $A 02$ value added as part of this industry total output in the Baltic States and Finland during the period from 2000 to 2014. Let us explain that, for example, in relation to Table $1,0.34=424: 1248$. Figure 1 shows the industry $A 02$ value added (as part of this industry total output) time series and corresponding trend lines graphically.

Our attention is drawn to the critically low value added as share in the total output in Latvia's industry $A 02$, when compared with Lithuania, Estonia and especially with Finland. For instance, in 2014 value added in Latvia's forestry and logging industry (as share in total output of this industry) is 
0.34. At the same time this indicator in Lithuania's industry $A 02$ is 0.45 , in Estonia's industry $A 02$ is 0.43 and in Finland's industry $A 02$ this indicator is 0.71 .

Table 2

Value added created by the industry "Forestry and logging" and total value added in the Baltic States and Finland, compiled in current prices, expressed in millions of US dollars; 2014

\begin{tabular}{|c|c|c|c|}
\hline $\mathbf{2 0 1 4}$ & VA in $\boldsymbol{A 0 2}$ & VA in total & VA in $\boldsymbol{A 0 2}:$ VA in total \\
\hline LTA & 424 & 28,178 & 0.015 \\
\hline LTU & 210 & 43,929 & 0.005 \\
\hline EST & 296 & 23,690 & 0.012 \\
\hline FIN & 4,461 & 239,192 & 0.019 \\
\hline
\end{tabular}

Table 3

Time series v(LTA;A02; $t), v(L T U ; A 02 ; t), v(E S T ; A 02 ; t), v(F I N ; A 02 ; t)$

\begin{tabular}{|c|c|c|c|c|c|c|c|c|c|c|c|c|c|c|c|}
\hline Year & 2000 & 2001 & 2002 & 2003 & 2004 & 2005 & 2006 & 2007 & 2008 & 2009 & 2010 & 2011 & 2012 & 2013 & 2014 \\
\hline LTA & 0.46 & 0.40 & 0.50 & 0.46 & 0.37 & 0.38 & 0.36 & 0.43 & 0.42 & 0.47 & 0.43 & 0.36 & 0.33 & 0.34 & 0.34 \\
\hline LTU & 0.57 & 0.58 & 0.58 & 0.61 & 0.60 & 0.57 & 0.58 & 0.57 & 0.57 & 0.59 & 0.59 & 0.50 & 0.44 & 0.45 & 0.45 \\
\hline EST & 0.41 & 0.38 & 0.38 & 0.38 & 0.37 & 0.38 & 0.37 & 0.44 & 0.40 & 0.41 & 0.39 & 0.42 & 0.43 & 0.43 & 0.43 \\
\hline FIN & 0.75 & 0.73 & 0.72 & 0.70 & 0.67 & 0.66 & 0.65 & 0.69 & 0.69 & 0.68 & 0.69 & 0.69 & 0.69 & 0.70 & 0.71 \\
\hline
\end{tabular}

In Table 3 the parameters $a, b, c$ of the value added trend lines in the functional form $w=a \cdot \tau^{b}+c$ are given. Serious anxiety arises in the shape of Latvia's A02 value added trend line, what is a decreasing concave; the derivative of the trend in the last year equals -0.0005 , what is the worst indicator, when compared with the other reference group countries. Apparently, the best trend lines shape (increasing convex) is for Estonia; the derivative of the trend in the last year equals +0.0002 .

As a quantitative indicator for industry dynamic regularity or convulsively measurement the author offers the coefficient of variation calculated using trend corrected data. As an example in Table 4 trend corrected data for $L T A$ are shown. The coefficient of variation of trend corrected value added as industry $A 02$ dynamic's regularity indicator is: 0.12 for $L T A ; 0.10$ for $L T U ; 0.06$ for EST; 0.03 for FIN.

In the author's opinion these indicators give the first answer about the low value added causality in Latvia's forestry and logging industry. Indicator 0.12 in LTA versus 0.03 in FIN signalizes about convulsivelity (volatility) versus regularity. The convulsivelity of value added created by Latvia's $A 02$ industry can also be clearly recognised in Figure 1.

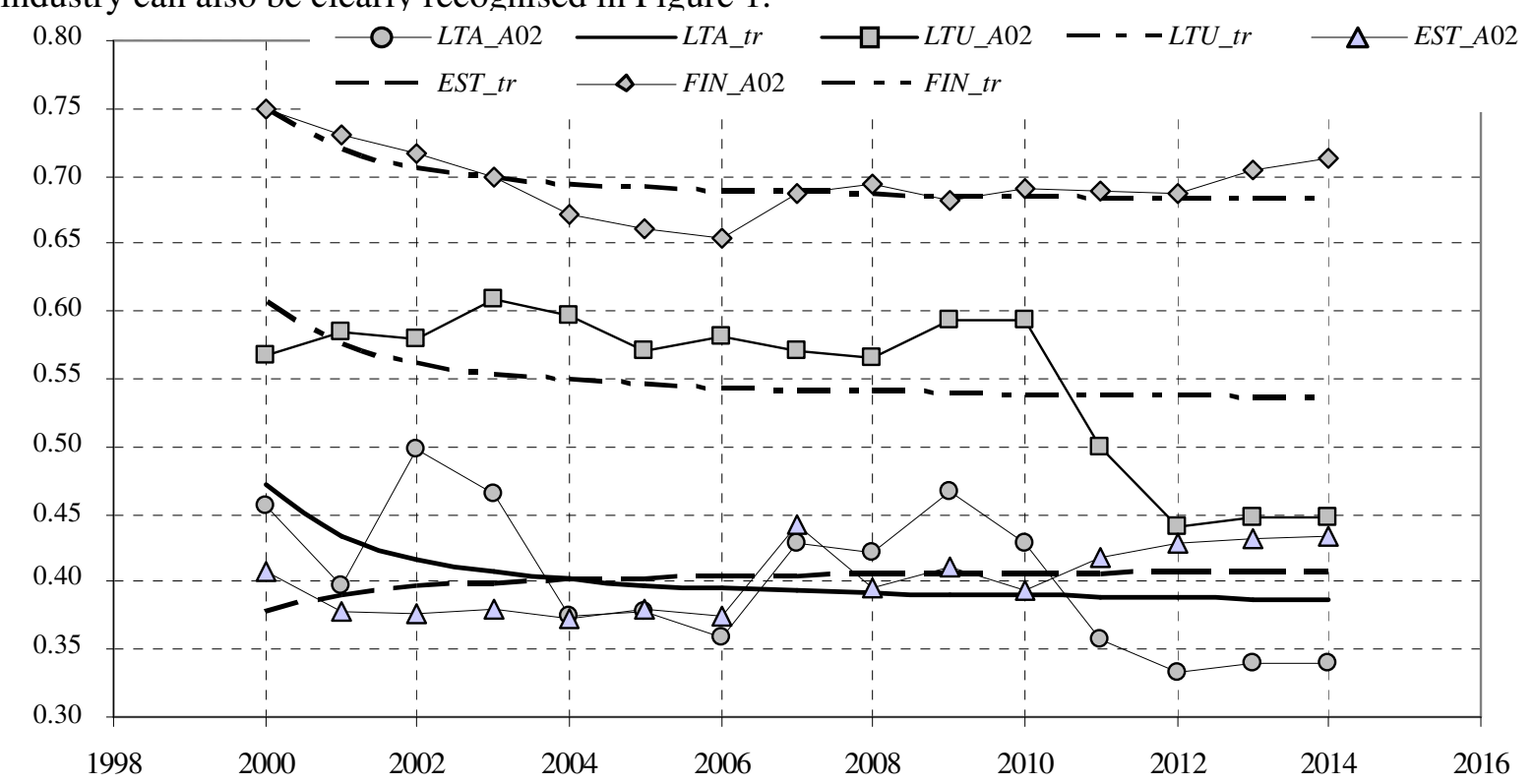

Fig. 1. Time series $\{v(L T A ; A 02 ; t), v(L T U ; A 02 ; t), v(E S T ; A 02 ; t), v(F I N ; A 02 ; t) \mid$ $t \in[2000 ; 2014]\}$ and corresponding trend lines in functional form $v=a \cdot \tau^{b}+c$ 
Trend lines in the functional form $v=a \cdot \tau^{b}+c, \tau=t-1998, t \in[2000 ; 2014]$.

Table 4

Value of the derivative $v^{\prime}=a \cdot b \cdot \tau^{b-1}$ in 2014

\begin{tabular}{|c|c|c|c|c|c|c|}
\hline $\boldsymbol{A 0 2}$ & $\boldsymbol{a}$ & $\boldsymbol{b}$ & $\boldsymbol{c}$ & $\uparrow$ or $\downarrow$ & $\cap$ or $\cup$ & $\boldsymbol{w}^{\prime}(\mathbf{2 0 1 4})$ \\
\hline $\boldsymbol{L T A}$ & 0.24 & -1.38 & 0.38 & decreasing & concave & -0.0005 \\
\hline $\boldsymbol{L T \boldsymbol { U }}$ & 0.19 & -1.36 & 0.53 & decreasing & concave & -0.0004 \\
\hline $\boldsymbol{E S T}$ & -0.07 & -1.26 & 0.41 & increasing & convex & 0.0002 \\
\hline $\boldsymbol{F I N}$ & 0.18 & -1.35 & 0.68 & decreasing & concave & -0.0004 \\
\hline
\end{tabular}

Table 5

$L T A, A 02$ value added (as part of total output) time series

\begin{tabular}{|c|c|c|c|c|c|c|c|c|c|c|c|c|c|c|c|}
\hline year & 2000 & 2001 & 2002 & 2003 & 2004 & 2005 & 2006 & 2007 & 2008 & 2009 & 2010 & 2011 & 2012 & 2013 & 2014 \\
\hline primary data & 0.46 & 0.40 & 0.50 & 0.46 & 0.37 & 0.38 & 0.36 & 0.43 & 0.42 & 0.47 & 0.43 & 0.36 & 0.33 & 0.34 & 0.34 \\
\hline trend corrected data & 0.37 & 0.35 & 0.47 & 0.44 & 0.36 & 0.37 & 0.35 & 0.42 & 0.42 & 0.46 & 0.43 & 0.36 & 0.33 & 0.34 & 0.34 \\
\hline
\end{tabular}

In order to take another point of view on the industry $A 02$ behaviour in the last year reported in WIOD five years, the trend lines in the parabolic functional form $v=a \cdot \tau^{2}+b \cdot \tau+c$ are calculated (Figure 2, Table 5). The five year trends demonstrate a positive slope for LTA, LTU, FIN, and a negative slope for EST.

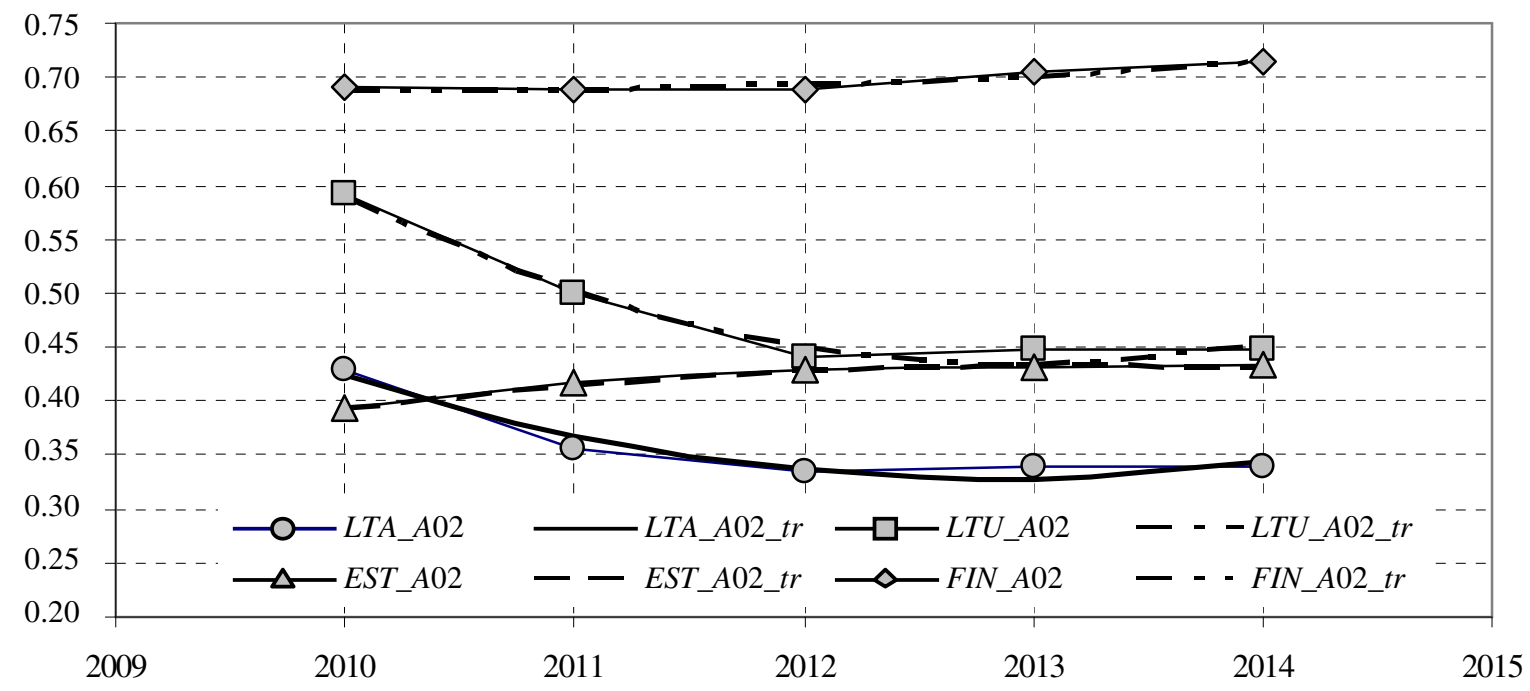

Fig. 2. Time series $\{v(L T A ; A 02 ; t), v(L T U ; A 02 ; t), v(E S T ; A 02 ; t), v(F I N ; A 02 ; t)$ । $t \in[2010 ; 2014]\}$ and corresponding trend lines in functional form $v=a \cdot \tau^{2}+b \cdot \tau+c$

Table 6

Trend lines in the functional form $v=a \cdot \tau^{2}+b \cdot \tau+c, \tau=t-1998, t \in$ [2010; 2014].

Value of the derivative $v^{\prime}=2 a \cdot \tau+b$ in 2014

\begin{tabular}{|c|c|c|c|c|c|}
\hline $\boldsymbol{A 0 2}$ & $\boldsymbol{a}$ & $\boldsymbol{b}$ & $\boldsymbol{c}$ & $\cap$ or $\cup$ & $\boldsymbol{v}^{\prime}(\mathbf{2 0 1 4})$ \\
\hline $\boldsymbol{L T A}$ & 0.0119 & -0.3541 & 2.9535 & concave & 0.0279 \\
\hline $\boldsymbol{L T U}$ & 0.0177 & -0.5283 & 4.3866 & concave & 0.0366 \\
\hline $\boldsymbol{E S T}$ & -0.0041 & 0.1239 & -0.5045 & convex & -0.0068 \\
\hline $\boldsymbol{F I N}$ & 0.0023 & -0.0570 & 1.0490 & concave & 0.0151 \\
\hline
\end{tabular}

2. What are the opportunity losses in Latvia's GDP as caused by the comparative inefficiency of the industry "Forestry and logging"?

Economic indicators obtained from NIOT allow us to estimate the efficiency of Latvia's industry A02, when compared with the respective industry efficiency in the other Baltic States and Finland. Table 7 reflects results of such comparison with Finland's "Forestry and logging". The analysis shows that huge opportunity reserves were not employed in the period of 2000-2014. The conclusion is: if the 
value added creation productivity of the industry A02 in Latvia would be equal to Finland's proper productivity ceteris paribus, the Latvia's GDP would increase by 3524 millions of USD.

Let us note that in 2012, 2013 and 2014 the opportunity losses exceeded the value added and trend of opportunity losses increases upsetting.

Table 7

Opportunity losses in GDP due to comparative inefficiency of the industry "Forestry and logging" compiled in current prices, expressed in millions of US dollars

\begin{tabular}{|c|c|c|c|c|c|c|}
\hline year & $\begin{array}{c}\text { LTA A02 } \\
\text { total output }\end{array}$ & $\begin{array}{c}\text { LTA A02 } \\
\text { part of } \\
\text { value } \\
\text { added }\end{array}$ & $\begin{array}{c}\text { LTA A02 } \\
\text { value } \\
\text { added }\end{array}$ & $\begin{array}{c}\text { FIN } \\
\text { part of } \\
\text { value } \\
\text { added }\end{array}$ & $\begin{array}{c}\text { LTA A02 } \\
\text { opportunity value } \\
\text { added if } F I N \\
\text { efficiency }\end{array}$ & $\begin{array}{c}\text { Opportunity losses in } L T A \text { A02 } \\
\text { value added do to comparative } \\
\text { inefficiency }\end{array}$ \\
\hline 2000 & 241 & 0.4554 & 110 & 0.7501 & 181 & 71 \\
\hline 2001 & 262 & 0.3980 & 104 & 0.7305 & 192 & 87 \\
\hline 2002 & 311 & 0.4986 & 155 & 0.7175 & 223 & 88 \\
\hline 2003 & 362 & 0.4644 & 168 & 0.6987 & 253 & 156 \\
\hline 2004 & 524 & 0.3738 & 196 & 0.6716 & 352 & 149 \\
\hline 2005 & 528 & 0.3783 & 200 & 0.6612 & 349 & 246 \\
\hline 2006 & 670 & 0.3594 & 241 & 0.6537 & 438 & 276 \\
\hline 2007 & 951 & 0.4276 & 407 & 0.6868 & 653 & 168 \\
\hline 2008 & 1015 & 0.4216 & 428 & 0.6936 & 704 & 291 \\
\hline 2009 & 777 & 0.4659 & 362 & 0.6822 & 530 & 408 \\
\hline 2010 & 1110 & 0.4292 & 477 & 0.6911 & 767 & 393 \\
\hline 2011 & 1226 & 0.3568 & 437 & 0.6896 & 846 & 460 \\
\hline 2012 & 1111 & 0.3338 & 371 & 0.6876 & 764 & 467 \\
\hline 2013 & 1261 & 0.3393 & 428 & 0.7042 & 888 & $\mathbf{3 5 2 4}$ \\
\hline 2014 & 1248 & 0.3393 & 424 & 0.7137 & 891 & Total: \\
\hline & & & & & & \\
\hline
\end{tabular}

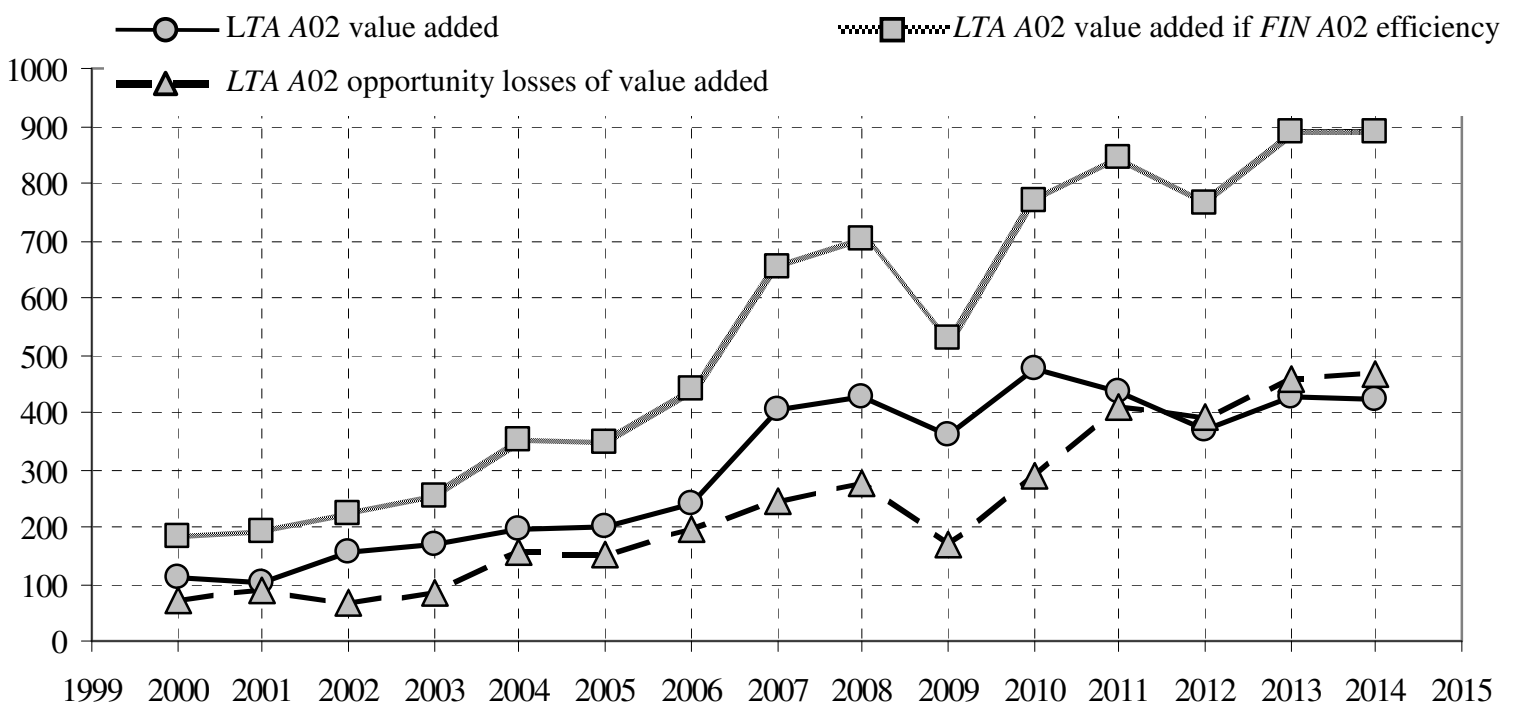

Fig. 3. Graphical visualisation of contents of Table 6

3. What production features cause the comparative inefficiency of the value added creation in the Latvian industry "Forestry and logging"?

\subsection{Domestic and foreign direct intermediate consumption}

NIOT may be used to carry out the comparative analysis of the A02 interindustry direct demand coefficients in Latvia and Finland. We are interested in two kinds of ratios: "LTA domestic purchases 
per unit of total output against FIN domestic purchases per unit of total output" (Table 8) and "LTA foreign purchases per unit of total output against FIN foreign purchases per unit of total output" (Table 9). The results present surprising differences in the structure and volume of domestic and foreign purchases for intermediate consumption in the production process. The results are expounded in Tables 8 and 9. Apparently, in order to produce a unit of product, the Latvian industry A02 expends sufficiently more resources then the respective Finland's industry. The format of the current paper does not allow for a detailed analysis of the reasons of such differences in the intermediate consumption structure and for the discussion of dissipating of the resources as well. Now we would only like to draw attention to the absolutely enigmatic huge intermediate consumption of the industry C16 products (99 millions USD) instead of only 2 million of respective consumption in Finland. The ratio for the domestic purchases is 211.25 and for foreign purchases is 56.23.

Table 8

LTA, FIN industry A02, 2014. Intermediate consumption (domestic purchases) in absolute terms (millions of USD) and per unit of total output

\begin{tabular}{|c|c|c|c|c|c|c|}
\hline Code & Title of industry & $\begin{array}{c}F I N \\
\text { domestic } \\
\text { purchases }\end{array}$ & $\begin{array}{c}L T A \\
\text { domestic } \\
\text { purchases }\end{array}$ & $\begin{array}{c}\text { FIN } \\
\text { domestic } \\
\text { purchases } \\
\text { per unit of } \\
\text { total output }\end{array}$ & \begin{tabular}{|c|} 
LTA \\
domestic \\
purchases \\
per unit of \\
total output
\end{tabular} & $\begin{array}{l}\text { Ratio } \\
(\mathbf{6}):(5)\end{array}$ \\
\hline 1 & 2 & 3 & 4 & 5 & 6 & 7 \\
\hline H52 & Warehousing and support activities for transportation & 0 & 28 & 0.0000 & 0.0226 & 960.83 \\
\hline $\mathrm{C} 16$ & $\begin{array}{l}\text { Manufacture of wood and of products of wood and } \\
\text { cork, except furniture; manufacture of articles of } \\
\text { straw and plaiting materials }\end{array}$ & 2 & 99 & 0.0004 & 0.0793 & 211.25 \\
\hline C33 & Repair and installation of machinery and equipment & 1 & 4 & 0.0001 & 0.0030 & 26.22 \\
\hline $\mathrm{F}$ & Construction & 0 & 2 & 0.0001 & 0.0017 & 22.54 \\
\hline $\mathrm{C} 30$ & Manufacture of other transport equipment & 0 & 1 & 0.0000 & 0.0004 & 19.83 \\
\hline $\mathrm{H} 49$ & Land transport and transport via pipelines & 16 & 53 & 0.0026 & 0.0422 & 16.22 \\
\hline C31_C32 & Manufacture of furniture; other manufacturing & 0 & 1 & 0.0001 & 0.0006 & 12.61 \\
\hline M69_M70 & $\begin{array}{l}\text { Legal and accounting activities; activities of head } \\
\text { offices; management consultancy activities }\end{array}$ & 8 & 19 & 0.0013 & 0.0150 & 11.86 \\
\hline J62_J63 & $\begin{array}{l}\text { Computer programming, consultancy and related } \\
\text { activities; information service activities }\end{array}$ & 5 & 12 & 0.0009 & 0.0100 & 11.75 \\
\hline G47 & $\begin{array}{l}\text { Retail trade, except of motor vehicles and } \\
\text { motorcycles }\end{array}$ & 22 & 44 & 0.0036 & 0.0356 & 9.97 \\
\hline B & Mining and quarrying & 0 & 1 & 0.0001 & 0.0006 & 9.72 \\
\hline K65 & $\begin{array}{l}\text { Insurance, reinsurance and pension funding, except } \\
\text { compulsory social security }\end{array}$ & 2 & 3 & 0.0003 & 0.0026 & 8.79 \\
\hline M73 & Advertising and market research & 1 & 1 & 0.0001 & 0.0009 & 7.95 \\
\hline M71 & $\begin{array}{l}\text { Architectural and engineering activities; technical } \\
\text { testing and analysis }\end{array}$ & 0 & 1 & 0.0001 & 0.0005 & 7.27 \\
\hline K66 & $\begin{array}{l}\text { Activities auxiliary to financial services and } \\
\text { insurance activities }\end{array}$ & 5 & 3 & 0.0008 & 0.0024 & 3.21 \\
\hline J61 & Telecommunications & 4 & 2 & 0.0006 & 0.0017 & 2.79 \\
\hline P85 & Education & 1 & 1 & 0.0002 & 0.0005 & 2.28 \\
\hline K64 & $\begin{array}{l}\text { Financial service activities, except insurance and } \\
\text { pension funding }\end{array}$ & 35 & 14 & 0.0056 & 0.0116 & 2.08 \\
\hline $\mathrm{N}$ & Administrative and support service activities & 29 & 12 & 0.0047 & 0.0096 & 2.03 \\
\hline L68 & Real estate activities & 19 & 8 & 0.0030 & 0.0060 & 1.99 \\
\hline GO & Output at basic prices & 6251 & 1248 & 1 & 1 & \\
\hline
\end{tabular}

According to the information available in mass media the officials of the industry A02 in Latvia do not worry about the low 34 cents of value added in the 1 euro total output (Table 3 ). For example, the member of the board of "Latvijas Valsts Meži" Edvīns Zakovics asserts that Latvia is the most competitive among the Baltic States. "We have experienced strong development during the independence period, we have learned how to sell our products." (This text is a free translation by the author from Latvian, LETA, 17.07.2017.). 
LTA, FIN industry A02, 2014. LTA foreign purchases per unit of total output: FIN foreign

Table 9 purchases per unit of total output

\begin{tabular}{|l|l|r|}
\hline Code & \multicolumn{1}{|c|}{ Title of industry } & Ratio \\
\hline C30 & Manufacture of other transport equipment & 154.05 \\
\hline C28 & Manufacture of machinery and equipment n.e.c. & 65.83 \\
\hline C16 & $\begin{array}{l}\text { Manufacture of wood and of products of wood and cork, except furniture; manufacture of articles of straw } \\
\text { and plaiting materials }\end{array}$ & $\mathbf{5 6 . 2 3}$ \\
\hline C33 & Repair and installation of machinery and equipment & 38.86 \\
\hline H49 & Land transport and transport via pipelines & 30.10 \\
\hline K65 & Insurance, reinsurance and pension funding, except compulsory social security & 12.91 \\
\hline C22 & Manufacture of rubber and plastic products & 11.50 \\
\hline C31_C32 & Manufacture of furniture; other manufacturing & 9.99 \\
\hline$H 52$ & Warehousing and support activities for transportation & 9.68 \\
\hline C19 & Manufacture of coke and refined petroleum products & 7.74 \\
\hline M71 & Architectural and engineering activities; technical testing and analysis & 7.55 \\
\hline J62_J63 & Computer programming, consultancy and related activities; information service activities & 7.50 \\
\hline$B$ & Mining and quarrying & 4.83 \\
\hline
\end{tabular}

Māris Liopa, the Head of the Latvian Forest Certification Council is more critical: "The economy of Finland is far ahead in their development in comparison with the Latvian economy, this is the reason why we used to exploit the Finnish experience. It seems quite normal to study Finland's' experience in such an industry as forestry. Latvia, just like Finland, owns large areas of forests, and forestry is one of the cornerstones of the national economy in both countries." (A free translation by author from Latvian, Delfi, 28.01.2018.) Māris Liopa mentiones the Finland's' Forestry Rule accepted in 2014 as a pattern for easy forest management.

\subsection{Interindustry direct and total requirement coefficients between $A 02$ and $C 16$ in $L T A, L T U$, EST, FIN in 2014}

In spite of the optimistic economic estimates for the industry $A 02$ by some officials already in the paper [3] an input-output framework showed the comparative weakness of the industry A02 total factor productivity. As proved by this paper the most serious reason of relative inefficiency of the industry $A 02$ in Latvia is wasting of resources. As it was mentioned in the introduction, the rigorous analysis of the Latvian industry A02 production dissipating features would be conducted together with experts of the respective industry. In this paper the author would like to specially stress the industries' $A 02$ purchases from the industry $C 16$. Let us consider direct requirement coefficients and total requirement coefficients as links between the industries $A 02$ and $\mathrm{C} 16$.

Table 10 provides data to compare the Latvian A02 direct domestic purchase from the industry $C 16$ which amount tore 0.0793 with the analogous direct purchases in LTU, EST, FIN: 0.0020; 0.0154; 0.0004. Considerable differences are observed between imported 0.0147 and proper volumes: 0.0003 ; $0.0020 ; 0.0003$.

Table 10

Interindustry direct requirement coefficients between A02, C16 in LTA, LTU, EST, FIN in 2014

\begin{tabular}{|c|c|c|c|c|c|c|c|c|c|c|c|c|}
\hline & LTA & 2014 & & $L T U$ & 2014 & & $E S T$ & 2014 & & FIN & 2014 \\
\hline & & $A 02$ & $C 16$ & & $A 02$ & $C 16$ & & $A 02$ & $C 16$ & & $A 02$ & $C 16$ \\
\hline$A 02$ & Domestic & 0.2396 & 0.1916 & $A 02$ & 0.2014 & 0.0554 & $A 02$ & 0.0969 & 0.1457 & $A 02$ & 0.1567 & 0.2898 \\
\hline$C 16$ & Domestic & 0.0793 & 0.1689 & $C 16$ & 0.0020 & 0.0487 & $C 16$ & 0.0154 & 0.1265 & $C 16$ & 0.0004 & 0.1002 \\
\hline$A 02$ & Import & 0.0108 & 0.0088 & $A 02$ & 0.0318 & 0.0092 & $A 02$ & 0.0080 & 0.0125 & $A 02$ & 0.0028 & 0.0053 \\
\hline$C 16$ & Import & 0.0147 & 0.0378 & $C 16$ & 0.0003 & 0.0617 & $C 16$ & 0.0020 & 0.0898 & $C 16$ & 0.0003 & 0.0166 \\
\hline & In total & 0.3443 & 0.4070 & & 0.2354 & 0.1750 & & 0.1223 & 0.3745 & & 0.1601 & 0.4119 \\
\hline
\end{tabular}


Table 11 contains the part of the Leontief inverse. The comparison of the Latvian A02 total domestic requirement 0.1304 versus the respective total requirements in LTU, EST, FIN: 0.0032; 0.0212; 0.0010 confirms our thesis about impenetrable waste of resources. Considerable differences are also observed between total requirement of imported resources: 0.0250 versus the proper: 0.0012 ; $0.0052 ; 0.0004$.

Table 11

Interindustry total requirement coefficients between A02, C16 in LTA, LTU, EST, FIN in 2014

\begin{tabular}{|c|c|c|c|c|c|c|c|c|c|c|c|c|}
\hline & LTA & 2014 & & $L T U$ & 2014 & & $E S T$ & 2014 & & FIN & 2014 \\
\hline & & $A 02$ & $C 16$ & & $A 02$ & $C 16$ & & $A 02$ & $C 16$ & & $A 02$ & $C 16$ \\
\hline$A 02$ & Domestic & 1.3485 & 0.3117 & $A 02$ & 1.2525 & 0.0731 & $A 02$ & 1.1113 & 0.1861 & $A 02$ & 1.1867 & 0.3852 \\
\hline$C 16$ & Domestic & 0.1304 & 1.2350 & $C 16$ & 0.0032 & 1.0521 & $C 16$ & 0.0212 & 1.1500 & $C 16$ & 0.0010 & 1.1142 \\
\hline$A 02$ & Import & 0.0157 & 0.0142 & $A 02$ & 0.0398 & 0.0120 & $A 02$ & 0.0091 & 0.0159 & $A 02$ & 0.0033 & 0.0071 \\
\hline$C 16$ & Import & 0.0250 & 0.0516 & $C 16$ & 0.0012 & 0.0658 & $C 16$ & 0.0052 & 0.1049 & $C 16$ & 0.0004 & 0.0190 \\
\hline & In total & 1.5196 & 1.6125 & & 1.2968 & 1.2029 & & 1.1468 & 1.4569 & & 1.1915 & 1.5255 \\
\hline
\end{tabular}

\section{Conclusions}

1. The comparative dynamic analysis of value added created by the industry $A 02$ (Forestry and logging) in the Baltic States (LTA, LTU, EST) and Finland (FIN) for the period of 2000-2014 demonstrates the critically low value added in Latvia's industry $A 02$, when compared with Lithuania, Estonia and especially with Finland.

2. The coefficient of variation for value added in the industry A02 during the period of 2000-2014 calculated using trend corrected data is 0.12 in LTA versus 0.03 in FIN what signalizes about convulsivelity (volatility) of industry dynamic versus regularity.

3. The most important reason for the significant comparative efficiency weakness of the industry A02 economic is the imperfect structure of the required resources vector, what implies costly domestic and foreign purchases. For example, the intermediate consumption of the industries' $C 16$ products with respect to a unit of total output in the industry $A 02$ in Latvia is 211 times bigger than in Finland.

4. The comparative dynamic interindustry analysis provided by using the Input-Output models and the World Input-Output Database (WIOD) with its unified structured statistical information as the empirical material is a powerful applied research method in economics. Our current relative unpretentious study assures us about the necessity of complete and complex investigation of all Latvia's 56 industries by using the respective Input-Output tools in order to establish the opportunity losses caused by the interindustry structural imperfectness.

\section{References}

[1] Miller R.E. Input-output analysis. Foundations and extensions. Second Edition. - Cambridge University Press, 2013, 750 p.

[2] Blomqvist Ä., Wonnacott P., Wonnacott R. Economics. Third Canadian Edition. - McGraw-Hill Ryerson Limited, 1990, $795 \mathrm{pp}$.

[3] Jaunzems A. Methods of measuring industry total factor productivity within an input-output framework. 16th International Scientific Conference on Engineering for Rural Development, Proceedings, Volume 16, Jelgava, Latvia, 24 - 26 May, 2017, pp. 383-392.

[4] Value added. [online][19.03.2018] Available at: http://www.ecb.europa.eu/home/glossary/html/glossv.en.html.

[5] Eurostat. Statistics explained - Intermediate consumption. [online][19.03.2018] Available at: http://epp.eurostat.ec.europa.eu/statistics_explained/index.php/Glossary:Intermediate_consumptio $\mathrm{n}$.

[6] Eurostat. Statistics explained - Gross value added. [online][19.03.2018] Available at: http://epp.eurostat.ec.europa.eu/statistics_explained/index.php/Glossary:Gross_value_added. 